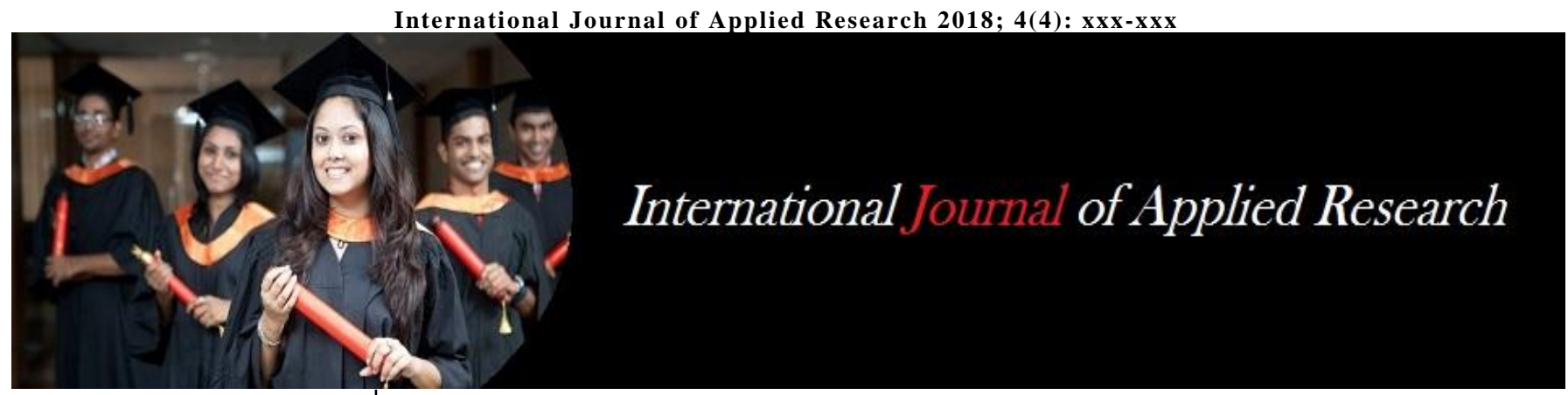

ISSN Print: 2394-7500 ISSN Online: 2394-5869 Impact Factor: 5.2

IJAR 2018; 4(4): 100-114 www.allresearchjournal.com

Received: 18-02-2018 Accepted: 21-03-2018

Damianus Abun

Ph.D, Faculty of the College of Business Administration of Divine Word College of Vigan, Ilocos Sure, Philippines

Sylvia Lalaine Grace L Foronda Ph.D, Faculty of the College of Business Administration of Divine Word College of Laoag, Ilocos Norte, Philippines

\section{Frederick Agoot}

MAME, faculty of the College of Education of Divine Word College of Vigan Ilocos Sur, Philippines

Maria Luisita V Belandres, MAMATH, Faculty of the Senior High School of Divine Word College of Bangued, Abra, Philippines

Theogenia Magallanez, Ed.D, Faculty of the College of Education of Divine Word College of Vigan, Ilocos Sur, Philippines
Correspondence Damianus Abun Ph.D, Faculty of the College of Business Administration of Divine Word College of Vigan, Ilocos Sure, Philippines

\section{Measuring entrepreneurial attitude and entrepreneurial intention of ABM grade XII, Senior High School Students of Divine Word Colleges in Region I, Philippines}

\author{
Damianus Abun, Sylvia Lalaine Grace L Foronda, Frederick Agoot, \\ Maria Luisita V Belandres, Theogenia Magallanez
}

\begin{abstract}
The purpose of the study was to determine the level of entrepreneurial attitude and entrepreneurial intentions of ABM Grade XII of Senior High School students of Divine Word Colleges in Region I, Philippines. The study uses quantitative descriptive research design and explanation research to describe and explain the entrepreneurial attitude and intentions of the students. In order to gather the data, questionnaires were used and the respondents were all ABM grade XII of the three schools, a total of 162 students. The findings reveal that as a whole entrepreneurial attitude of students is high and their entrepreneurial intention is also high. In terms of its correlation, the study found that there is a significant relationship between entrepreneurial attitude and intention.
\end{abstract}

Keywords: Entrepreneurial attitude, entrepreneurial intention, need for achievement, need for autonomy, creative tendency, calculated risk taking, drive and determination

\section{Introduction}

There is no doubt that the world economy is solely supported by business. The progress of a country is determined by the business. The economic growth of a country is a reflection of the growth of business. No economic growth is a sign of no economic activity and consequently poverty stays or grows.

The economic growth is usually measured by GDP growth. According to the World Bank, world economy is forecasted to grow up to 3.1 percent in 2018 as the recovery in investment, manufacturing, and trade continues. This growth is supported by the growth of different countries. As a whole, growth in advanced economies is expected to moderate slightly to 2.2 percent in 2018. For the meantime, growth in emerging market and developing economies as a whole is projected to strengthen to 4.5 percent in 2018 , as activity in commodity exporters continues to recover amid firming prices (The World Bank, 2018) ${ }^{[94]}$. These are signs of economic movement and these are indicators of measuring economic growth of the world.

In the Philippines the economic growth for 2018 is expected to grow to $6.7 \%$ and $6.8 \%$, respectively, from the previous $6.5 \%$ and $6.7 \%$. The growth is not only supported by government spending but also private investment. According to ADB (2005) in its Philippine Private Sector Assessment, that private firms contribute around 95\% of GDP and employed more than $90 \%$ of the workforce in the country (Paderanga, 2011) ${ }^{[71]}$. Such report indicates that the role of private investment is crucial to the economic growth and employment of the Philippines.

Based on 2016 MSME statistics, business establishments operating in the Philippines are a total of 915,726 . There was an increase of $1.64 \%$ more than 900,914 business establishments reported in 2015. Micro, small and medium enterprises (MSMEs) account for 99.57\% $(911,768)$ of the total establishments, of which $89.63 \%(820,795)$ were microenterprises, $9.50 \%(86,955)$ were small enterprises, and $0.44 \%(4,018)$ were medium enterprises. Large enterprises made up the remaining $0.43 \%(3,958)$. Thus based on such statistic, it points out the fact that the economy is supported by the MSMEs and even the employment. The one who created or established the MSMEs are the entrepreneurs. 
Entrepreneurs are defined as individual persons who do not want to be employed by the government or by other firms but creates their own business and employee themselves and others. These individuals are usually seen as an innovator, a source of new ideas, goods, services and business/or procedures (Investopedia, n.d). They play a key role in any economy. Without them the economy cannot go forward and poverty remains. These are the people who have the skills and initiative necessary to anticipate current and future needs and bring good new ideas to market. The purpose of opening business courses in senior high school and college is not to prepare individual persons for employment but they are prepared to be entrepreneurs. They are expected to open business in the future and create jobs for others. It is along such purpose, the current study would like to find out if ABM (Accounting, Business, Management) grade XII students of Senior High School of Divine Word Colleges have the entrepreneurial attitude and have the intentions to create business in the future.

\section{The Importance of the Study}

The output of the study will be useful for curriculum developers to redesign the content of the curriculum in order to match with the objective of such course to prepare students to be entrepreneurs. It can also be used to reorient the students about the basic purpose of their intention to take up ABM (Accounting, Business and Management) programs.

\section{Theoretical Framework Understanding Entrepreneurship}

Entrepreneurship is originated from French word, entreprendre, meaning "to undertake. It is to undertake new business ventures. There are many other definitions about entrepreneurship but there are no common agreements about the definitions. Commonly believe that entrepreneurship is the creation of new business. It begins with economic opportunities to exploit and the capital to turn the economic opportunity into real business. It begins with the journey of exploration and risk management to create value for profit and social good (Manisha \& Singh, 2016) [60]. Entrepreneurship has often been viewed through the image of the entrepreneur, the sole hero of modern times. Today entrepreneurship is regarded as one of the best economic development strategies to develop a country's economic growth. It is considered as a major engine driving many nations' economic growth, innovation and competitiveness. It is a strategy that can be used to solve poverty issues (Ressurection, 2011). Due to its importance to develop the economy, in recent years, the government's attention to entrepreneurship has been increasing and attention comes from educational sector and business support groups. Nurturing entrepreneurship has become an explicit policy priority for many governments (OECD, 2006) [69]. Entrepreneurship is viewed as a critical activity to regenerate and sustain economic growth in strong economies and also as a means of boosting employment and productivity in depressed regions or in developing countries. Recognizing the importance of entrepreneurship in terms of economic growth and employment, therefore acquiring entrepreneurship skills is the best option for every student who are interested to be entrepreneur in the future. It is important because it contributes to variety of benefits and functions that change individual's life (Abdul-Rahman,
2000; Sidek, 2008) ${ }^{[3,90]}$. This is the reason why the interest in learning entrepreneurship is increasing. It opens the eyes of many people or students to see opportunities (MohdSaleh, 2002) ${ }^{[64]}$. It is a reality that many college graduates are unable to find job after graduation because vacant job opportunities out there are limited, the competition is high. That is the main reason why entrepreneurship education is included in the school curriculum for the fact that students should not expect to be employed by others or by the government but to create job for themselves and by doing so they contribute to social and economic welfare (Ramos, 2014) ${ }^{[75]}$.

Who are the entrepreneurs? These are the people who see the economic opportunity, figures out a way to acquire the needed resources, and acts to turn the opportunity unto business opportunity. They use their financial resources to create business and employment and consequently improve well-being of the people or the community. Entrepreneurship can also help individuals, families, organizations, and communities turn opportunities into actions to maintain or increase well-being (Cox, 2011) ${ }^{[22]}$. Without entrepreneurs, the world economy cannot grow and prosperity cannot be achieved. They are the inventors who generate new ideas and finding ways create something new that is beneficial to the society. These are the people who will not just look around and see problems but when they look around, they will see opportunities. They are achievers who are willing to work long and hard to reach their personal goals. They like to plan and are committed to making things happen.

\section{The role of education in creating entrepreneurs}

The questions of how the university can contribute through education entrepreneurial mindsets. It is still debatable whether teachers in the classroom are the right people to teach entrepreneurship and if it can be learned. Some argue that the only way skills and entrepreneurial mindsets can be taught is by entrepreneurs themselves dissecting their successes and failures and sharing real-world, practical experience. It means that entrepreneurs should go to classroom and share their experience. Others say entrepreneurship cannot be taught; that successful entrepreneurs have distinct traits which are innate, and that certain people are hard-wired to see opportunities and pursue them through new and innovative means (Sarasvathy, 2015) ${ }^{[84]}$.

When we think of entrepreneurial mindset, it will be hard to reconcile with the traditional education that we have. The traditional education is teaching students with casual thinking method or predictive thinking (Sarasvathy, 2015) [84], in the sense that the students are taught how to go into business. She further says that when someone go to business, the first thing he/she should do is to scan the environment, envision the business, then establish the mission and objectives, determine key result areas, performance indicators and strategies. Students are taught that when they are following those standards of operating procedures, they would be successful. Such method may not work with those who have entrepreneurial mindsets and behaviors which are relying on creative thinking. Creativity is learned not through sitting down in the classroom but by experiencing and applying creative thinking processes. Robinson (n.d) challenges such traditional education. He contends that we learn to be innovative and entrepreneurial 
by exploring, questioning assumptions, using imagination and synthesizing information. Robinson asserts that traditional education's emphasis on conformity, compliance and a linear path stifles this (Rogan, 2015) ${ }^{[81]}$. Entrepreneurs are by nature effectual reasoning. They do not begin with a specific goal or mission or objective. Instead, it begins with a given set of means and allows goals to emerge contingently over time from the varied imagination and diverse aspirations of the founders and the people they interact with (Sarasvathy, 2015) ${ }^{[84]}$.

Going by the idea of effectual reasoning, now we have a problem of the relevance of education because effectual thinking is not necessarily learned in the classroom setting with a structured mindset, not creativity. Creativity is learned through the process of experience in the field. There is a disconnection between what is going on in the classroom and what is needed to improve the world. This is a particular challenge to all schools. Therefore Fadel (2016) ${ }^{\text {[29] }}$ suggest that there must be a closer relationship with the private sector and a tighter bond with companies, start-ups, and the job market, especially for secondary school students, as well as students in technical schools and universities. Through linkages, the school can translate knowledge into practice - converting the fundamental knowledge that grows at the school into real things and real actions that have real consequences for real people. And that translation at the school is entrepreneurship (Toone, 2016) ${ }^{[97]}$. Thus the concern of the schools is how to ensure that education delivers the right skills for the labor market and the growth of entrepreneurship. Fadel (2016) ${ }^{[29]}$ points out two challenges that education faces today. First is education and how to prepare young people for the jobs of tomorrow that do not exist today; and the second is building the economy of tomorrow, the digital economy, the fastest growing sector worldwide, the main driver of innovation and economic growth for the next 50 years. Both challenges are related to entrepreneurship. The skills and values of entrepreneurship are very clear: problem solving, critical thinking, team work and risk taking. Thus the concern here is how to educate students to be problem solver, critical thinker or creative thinker, risk taker and team worker. Though entrepreneurial attitude and behavior may not necessarily be learned in the classroom but it is still recognized that education is important to enhance this attitude and behavior in a better use. School enhances the entrepreneurial attitude by providing them skills that are necessary to handle business process and problem solving.

The world tomorrow is transferred to the youth of today who are still studying. They are entrusted not only to guard what we have now but to build and develop new ones. Therefore education must be able to educate the young generation with the skills and theories in business to be skillful entrepreneurs in the future because it is the entrepreneurs' job to shape the world by developing versatile skill sets and profitable businesses that are crucial to the progress of our economies (FULL FABRIC, 2017) [35]. This challenge demands the school or universities to create an educational environment that foster progressive ideas and innovation, and equip students with the practical knowledge and skills they need to navigate the choppy waters of business ownership. The objective of school curriculum, particularly undergraduate should mainly focus on awareness and motivation elements on becoming entrepreneur. At this level, entrepreneurship contents are to stimulate students' mindset in self-employment and business start-ups. The content of the curriculum and teaching strategies must be able to create a spirit of a fearless pursuit to push to the limits of conventional wisdom into previously unforeseen and uncommon directions. The objective of graduate and post graduate level is to deliver the necessary skills that relate to entrepreneurship. The contents involved are practical tools such as a business plan, marketing plan, and finance. The components in entrepreneurship education are essential because many scholars reported positive outcomes in the entrepreneurial intention (Abbas, 2013) ${ }^{[1]}$. In fact recent studies have pointed out that entrepreneurial attitude and intention as factors determining entrepreneurial behavior (Ajzen 1991, Fayolle \& Gailly 2005) ${ }^{[65,30]}$. These factors can be considerably influenced by entrepreneurship education (Fayolle et al. 2005, Hannan et al. 2004, Hannon 2005, Lüthje \& Franke 2003, 2004) ${ }^{[30,40,42,56]}$.

\section{Entrepreneurial Attitude}

Many people say that attitude matters. It influences a person to behave in a certain way. In fact the behavior of a person is a reflection of the attitude of the person and who the person is. Therefore Oberko (n.d) contends that entrepreneurs who want to see themselves at the top must take time to work on their attitude. Attitude is assumed to a better explanatory factor for a career choice than demographic variables (Robinson, Stimpson, Huefner \& Slatter, 1991) ${ }^{[80,79]}$. They argue that attitude influences confidence, enthusiasm, inclination and aspiration toward entrepreneurship. AJen (2002) defines entrepreneurship as a personal perception toward value, benefit and favorability of entrepreneurship which affect their intention to venture into a new business area. However, others offer different understanding about entrepreneurial attitude. For them, entrepreneurial attitude is not just a matter of personal perception but it is an individual feelings, thought and conations toward entrepreneurship. It is considered as a function of value, belief and favorability of entrepreneurship (Schultz \& Oskamp, 1996) ${ }^{[86]}$. Still others have seen entrepreneurial attitude as personality traits that are born with the person which include achievement oriented, innovation, and entrepreneurial esteem. As personality traits, entrepreneur has been defined as a maker of motivated decisions, and a bearer of risk, as one who undertakes to manage business ventures. Entrepreneur is seen as innovator (Schumpeter, 1934) ${ }^{[87]}$, an organizer and bearer of risk (Shapero, 1975). Newest literature has also characterized entrepreneur as a person who has great imagination, flexibility, creativeness and innovativeness; a person who is ready for conceptual thinking, who sees a change as an opportunity for business (Richards 1999, Kao et al. 2002, Timmons 1997) ${ }^{[78,48]}$.

Though academic literatures have different views on the entrepreneurial characteristics that are most important, however, building on definitions as well as the findings of literature review that we have presented above, we would like to highlight the following concepts about entrepreneurial attitude that we need to go further into the this study. The basic premise of the study is that the enterprising persons share the same entrepreneurial characteristics and these characteristics may be enhanced or nurtured through education (Caid, 2013). 


\section{Need for Achievement}

It has been argued that achievement motivation is the most prevalent theory of entrepreneurship (Johnson, 1990). The concept of Need for Achievement was originated by Henry Murray in $1938{ }^{[65]}$. Murray measured nAch with the Thematic Apperception test, where a subject writes a short story about a picture. (Graham, 1994) ${ }^{[39]}$. Later the theory was developed further by McClelland and according to him those who have high level of nAch exhibits a strong desire to assume personal responsibility, to set and meet moderately difficult goals, and to receive performance feedback. He believed that nAch was critical to economic development and proposed to provide developing countries with achievement training rather than financial assistance (Carney, 1995) ${ }^{[20]}$. McClelland's work on need achievement found nAch to be a key factor in entrepreneurship. Moreover, McClelland concluded that the relationship between nAch and entrepreneurship meant that nAch was essential to economic development, and that any country that wished to accelerate economic progress should be interested in raising levels of need for achievement within its borders (McClelland, 1961) ${ }^{[63]}$.

The study of McClelland may not be conclusive because it is a fact that some are supporting but many also not supporting the relationship between nAch and entrepreneurship. Babb and Babb, (1992) conducted a study that support the argument of Mcclelland that need for achievement was one trait that differentiated founders and no founders. An Indian study found achievement motivation to be one of seven important factors in the choice of an entrepreneurial career (Stimpson, Narayanan, \& Shanthakumar, 1993) ${ }^{[93]}$. Their studies indicate that achievement motivation is a valid predictor of entrepreneurial behavior. Sibin Wu (2007) also contends that need for achievement is found to be positively related to entrepreneurial persistence. However the ideas of McClelland are also rejected by some. There are also studies that are rejecting the association of need for achievement and entrepreneurship. Other studies argued that need for achievement cannot be universalized because there are cultural differences. Cultural background may affect the entrepreneurial attitude. The studies have found that cultural background has been seen to play a role in what one value (Landrine, 1992; Maehr \& Nicholls, 1980) ${ }^{[53,59]}$ and affect their entrepreneurial attitude. However, as a whole, majority researchers have found that there is interrelation between need for achievement and entrepreneurial attitude.

\section{Need for autonomy or independence}

It cannot be denied that need for autonomy is part of human natural tendency. It is inherent human nature (Ryan, 2015). Self - Determination Theory contends that human beings have the propensity to be curious about one's environment and interest in learning and developing one's knowledge. Autonomy represents an inner endorsement of one's actions - the sense that one's actions emanate from oneself

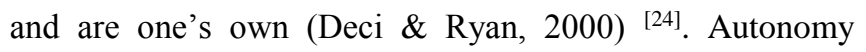
pertains to striving toward the development and realization of personal goals, values, and interests (Assor, Kaplan, \& Roth, 2002) ${ }^{[13]}$.This natural tendency has to be expressed because without it, the individual person may not be happy. However, often time this natural tendency cannot be developed into its full realization because of external control. That is why Angyal (1941) ${ }^{[10]}$ claims that personality develops in the context of two conflicting pressures, autonomy and surrender (or homonomy). The desire toward autonomy leads the individual person to be independent, and differentiated from other people and the environment. However, this tendency is met by a countervailing pull toward surrender, felt by the individual as a desire to become part of something greater than oneself, uniting with others and with the physical environment.

Theories that discuss about autonomy argue that individuals are motivated to have the freedom to determine their own direction, their actions and their own life unless it is blocked in some way (Deci and Ryan 1985) ${ }^{[23]}$. According to Deci and Ryan (1985) ${ }^{[23]}$ that major constraints on experiencing intrinsic motivation can include stable or transient individual differences in the ways that individuals make sense of events. The tension is experienced by the individual person when there is a confrontation between autonomy orientation and control orientation. Within such environment, the individual person may experience feelings of pressure and anxiety, and action comes to be viewed as controlled by either internal factors not of their making ((Deci and Ryan 1985) ${ }^{[23]}$. Both contend that autonomy is the foundation of motivation. For them autonomy is "behaving with full volition and choice."

According to Patel (2012) ${ }^{[72]}$ that basic motivation for entrepreneurs going into business is not simply to make money but beyond it is autonomy or freedom. Many people are not functioning well and cannot develop their own talent when they are employed by others or working under the control of others. Entrepreneurs display a strong desire for independence and freedom. They have the tendency to do things autonomously and such desire for independence and self-direction has been considered as a predictor of successful entrepreneur. It is always argued that autonomy is the primary sources of entrepreneurs venturing into different economic activities. It is considered as startup motivation because one wants to be free with regard to the what, how, and when aspects of work. They want to control their own destiny what they want to achieve in their life (Gelderen, Jansen \& Jonges, 2003). Autonomy is seen therefore as an instrument for the realization of a dream.

\section{Creative Tendency}

The game of business today to survive the competition is creativity and innovation. Creativity is defined as the tendency to generate ideas, alternatives, possibilities that may be useful in solving problems, communicating with others. It is also a capability to come up with new ideas to create solution to problems and exploit new opportunities. Creative thinker cannot just accept status quo or the old ways how things are done but one must question the status quo and introduce new ways of doing things. Business as usual is no longer the philosophy of business owner or entrepreneurs nowadays. Thus highly creative entrepreneurs are rule breakers who don't like to conform to norms and traditions of the industry. Business builders constantly look for way to propel their business forward. In this case, the nature of entrepreneur is constant change and therefore one must be comfortable with the unknown environment (Badal, n.d). Creative thinkers are alert to the changes in the environment and always looking for ways how to respond to the changes in the environment and even anticipate what is going to happen in the market. They always evaluate new possibilities, revise their expectations of the imagined 
future, and formulate fresh action plans to achieve their goals. This endless cycle of new information, new opportunities, and new action plans helps you start ventures or grow existing ones.

Creativity is not given but it is acquired through training or education. It is a skill that an entrepreneur needs to learn and master. Desai (2006) contends that creativity is an important characteristic for an entrepreneur. It was also found that there is a relationship between creative tendency and business success. Entrepreneurs 'mind resolve around new ideas and opportunities for innovation and for change. They continue to examine existing practices and devising ways in order to carry them out in a more efficient and effective way, in terms of both time and cost. In simple words, entrepreneurship works toward the optimization of business (Anastasia, 2015) [11]. They work toward optimizing resources and taking full use of them to create efficient processes. The whole process of entrepreneurship is rooted in creation and exploration of new ideas. When an entrepreneur is able to generate a new idea that is feasible as well as efficient, it gives him an edge over the competition. Creativity helps us think of how to improve existing business practices. It can come up with the most unthinkable ideas and bring innovation into existing practices. Rentschler (2010) ${ }^{[76]}$ in her study found that creativity is always associated with successful entrepreneurs.

\section{Calculated Risk Taking}

Creativity and Innovation cannot be separated from risk taking behavior because often time creativity and innovation have no $100 \%$ guarantee of success. Some may fail and some may succeed. There is always fear of failure and because of such fear, one can be discouraged to proceed with certain plan or program. Fear of failure is not the nature of entrepreneurs but he/she must be comfortable with uncertainties. However risk taking behavior does not mean recklessness but it is calculated risk taking. Calculated risk taking means that the enterprising person is opportunistic and seeks information and expertise to evaluate if it is worth pursuing the opportunity which will usually involve some risks (Caird, 2013) ${ }^{[19]}$. Entrepreneurs are characterized by a propensity to take calculated risks. Entrepreneurs know by instinct that gains do not accrue to those who always play safe. Entrepreneur who relentlessly pursues every possibility with little regard to available resources and the cautious entrepreneur who while taking some risks starting the business, may wish to preserve initial gains by taking calculated risks.

Calculated risk means that risk have to be calculated ahead before proceed and see to it that such venture will not be totally a lost. Entrepreneurship is always associated with risk and risk - taking. One of the most important factors in the entrepreneurs' success is their capability to take the risk. That is the only way in order to realize their ideas and dreams (Allah \& Nakhaie, 2011) ${ }^{[9]}$. There are several kinds of risks that an entrepreneur has to face and they are: financial risk, job risk if he fails, social and family risk, and mental risk (Allah \& Nakhaie, 2011) ${ }^{[9]}$. Financial risk will happen when the outcome of the venture does not make money. Job risk will be experienced if the venture does not prosper and it might be hard to go back to the old job. Social and family risk may occur particularly at the beginning of the undertaking which is time consuming. It can destroy family relationship. While mental risk is associated with psychological burden that one has to take during the process of putting up a business. It can cause stress and anxiety.

Others authors have classified risks into several categories such as risk as variance, risk as downside loss, and as opportunity cost (Duxbury \& Summers, 2004, Brown \& Warner, 1985, March \& Shapira, 1987; Shapira, 1994; Lumpkin \& Dess, 1996, Gimeno, Folta, Cooper \&

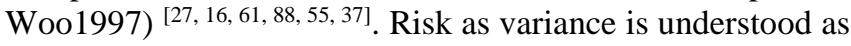
financial loss. It is classically measured financially as the stock market return in which changes in the firm's stock price can be largely attributed to specific outcomes. It emerges from measurements of financial leverage. Risk as downside loss is built upon the view that it may be better to forego a positive outcome if in doing so one must first accept a relatively greater possibility of a negative outcome (MacCrimmon\& Wehrung, 1986) ${ }^{[58]}$. Finally, risk as opportunity cost means that risk increases with rise in opportunity costs, that is, what entrepreneurs must give up to receive the potential upside gain. It has been argued that risk taking trait coupled with creativity and flexibility is considered a better indicator of the likelihood of starting a business than is achievement motivation.

In summary risk taking is not just about financial loss that an entrepreneur has to consider or calculate but other risk related to the growth and success of the ventures are considered risk that have to be calculated. Before pursuing the plan, one has to analyze the pros and cons if there is greater chance of winning or losing.

\section{Drive and Determination}

It cannot be denied that there is no success without determination. Drive and determination are essential ingredients of business success. Gould (2014) ${ }^{[38]}$ contends that drive is an inner quality that makes a person not just accepting status quo but challenging it. It is this drive that brings people to go higher and higher. Because of drive, people are not contented with what they have but they want something more. Drive pushes people to get out of comfort zone and look for new opportunities that can bring them somewhere. Drive in psychology is defined as an urgent basic need pressing for satisfaction because physiological tension, deficiency or imbalance (Encyclopedia Britanica, n.d). Psychological drives are also defined as desire of selfactualization, need for achievement, belongingness and status (BusinessDictionary, n.d). It is an inner arousal and internal motivation to reach a particular goal. There are two different drives and they are drive related to survival which may include the need for food, water and oxygen and acquired drive which is secondary in nature that include the drive for money, intimacy and social approval. Psychologist argues that drives motivate people to reduce desires by choosing responses that will most effectively do so (Hull, 1943) ${ }^{[45]}$. It is the motor principle inherent in living organisms that underlies, in the last instance, all their actions. A drive is activity.

English Dictionary defines determination as a quality that one shows when he/she has decided to do something and she/he will not let anything to stop him/her. However, psychologically, determination means perseverance toward the attainment of goal in spite of obstacles (Kirby, Morrow, J., \& Yih, 2014) ${ }^{[50]}$. It is a state of positive emotional feeling before the attainment of a goal and serves as a source of motivation of the person to pursue certain activity or business. It is an emotion that motivates individual to go 
into action and results in important outcomes. Under Selfdetermination Theory, self-determination means a volitional actions taken by people based on their own will and it comes from intentional and conscious choice and decision (Nota, Soresi, Ferrari, Wehmeyer, 2011) ${ }^{[68]}$. However, in the context of positive youth development, selfdetermination is not just a motivation but it is the ability to think for one's self and take action consistent with that thought (Catalano, et.al. 2004) ${ }^{[21]}$. The purpose of selfdetermination is autonomy, independent thinking, selfadvocacy, empowerment and the ability to live according to values and standards.

Determination is one of the traits that an entrepreneur has. It is what make one an entrepreneur. It is one of the causes why entrepreneur fails when he/she lacks of determination and persistence. It can also be called the will to power. Powered by determination, an entrepreneur would not be thwarted by their defeat but they look at defeat as an opportunity for success. They are determined to make all their endeavors succeed and when they fail, they learn from their failure and try again until they succeed (Adams, n.d). Determination is seen as more important than other factor that inspiring an entrepreneur. It makes an entrepreneur can overcome incredible obstacles and also compensate enormously for other weaknesses.

\section{Entrepreneurial Intentions}

Individual's entrepreneurial intentions are important variables to predict their entrepreneurial behaviors. Intentions may reflect into a concrete behavior. However, looking at the definition of intention, researchers have no identical definition about individual's entrepreneurial

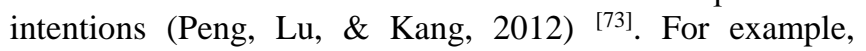
Francis and Banning (2001) ${ }^{[34]}$ defined intention as business orientation, while Korunka, et.al (2003) ${ }^{[52]}$ defined intention as nascent entrepreneur. Given those different definitions, this study defines the entrepreneurial intention as a mental orientation such as desire, wish and hope influencing their choice of entrepreneurship.

Entrepreneurial intention is considered as personal orientation toward owning a business in the future. Research confirms that entrepreneurial intentions play an important role in the decision to start a new firm. However, the reasons why individual persons go into business may vary depending on many reasons. Many say that a decision to leave a job and go into business can be either personal or organizational reasons; cultural or family background. Personal or psychological reasons why a person goes into business can be caused by the fact that the person has interest to go into business. He/she does not want to be under the control of other person. Those who need for independence may prefer to open their own business and to be the boss of his/her own business. He/she wants to be free and independent in terms of what he/she wants to do in his business. Other researchers also found that personality traits may affect individual's entrepreneurial intentions. They considered personality traits as an important factor. Entrepreneurs who show some personality traits such as strong achievement orientation, strong individual control, and willingness to take risks, endurance, and intelligence (Shaver, 1995) ${ }^{[89]}$ prefer to establish their own business and become boss for their own business rather than they are controlled by other people, though this might not be the single reason for going into business because other researchers hold that those personality traits cannot be taken as an effective explanation of their choice of starting business(Gartner, 1985) ${ }^{[36]}$.

Others also leave the job and go into business. It is because of some organizational problems that are not favorable to the employ and employer relationship (Lee, Wong,\& foo, 2009) ${ }^{[59]}$. When an employees feel that they are not happy and not growing if they continue to work with the same company, they left the company and established their own. There can be other factors such as culture and family background that encourages or discourage an individual person to go into business (Ozalli \&Rivenburg, 2015). There are cultures that encourage entrepreneurial behavior but some cultures are not. Even family background and training can become conducive environment for the entrepreneurial behavior to grow. Other researchers also contend that entrepreneurial intention can be caused by subjective reasons such as the expectation of the family, parents and from other important person who are closed or important to them (Krueger, 1993). They also found that entrepreneurship is associated with entrepreneurial attitude and mediated by intentions (Ajzen \& Fishbein, 1977) ${ }^{[5]}$.

\section{Related studies on entrepreneurial attitude, and entrepreneurial intention}

Knowing the important role of entrepreneurship in job creation and economic growth, there have been growing interest among many researchers to conducted studies on entrepreneurial attitude and entrepreneurial intentions among students. Those studies have been contributing to policy and curriculum development for the schools offering business courses. The intentions of those studies were trying to find out if students possessed entrepreneurial attitude and if those entrepreneurial attitude led to entrepreneurial intention in the future. Similarly, the intention of current study is to find out if students who are taking up accounting, business and management course have entrepreneurial attitude and have entrepreneurial intentions. Citing the importance of entrepreneurship, Bakotic and Kruzic (2010, cited by Sondari, 2014) ${ }^{[92]}$ state, that students are generators of the future economic development and their entrepreneurial attitudes and behavior determine the future business activities and sustainability of economy. Such statement was also repeated by The Global Report (2014) of the Global Entrepreneurship Monitor (GEM) which states that proactive approach in the developing of $\mathrm{EB}$ and enhancing entrepreneurial intentions requires consistent improving of entrepreneurship education (Singer, Amoros, Arreola, 2015) [91]. The literature review within entrepreneurial intentions confirms that entrepreneurship education programs are the right and effective for preparing students to be entrepreneurs. Kritskaya, (2015) [51] conducted a review of literature on the effect entrepreneurship education to the entrepreneurial intentions. As a result of the review, she confirms that entrepreneurship education programs are the right and effective tool to enhance entrepreneurial intentions. In consistence with the previous findings, Tshikovhi and Shambare (2015) [97] maintain that entrepreneurship education can influence the entrepreneurial knowledge and entrepreneurial attitude which consequently affect their entrepreneurial intentions. Such finding is also forwarded by the study of Sataniewski (2015) ${ }^{[85]}$ on student readiness to start their own business among Polish students. His study confirmed that Polish 
students exhibit substantial interest in starting their own businesses. There was an association between academic program and student readiness to start their own business. Dogan (2015) ${ }^{[26]}$ in his study on the relationship between entrepreneurial education and entrepreneurial intention concluded that there was significant positive correlation between the students' success levels in the entrepreneurship class and their entrepreneurial intentions. The interest of the students in entrepreneurship education is also showing an increase in recent years (Rudhumbu, 2016) ${ }^{[82]}$.

Cross cultural study on the effect of personality trait and entrepreneurial intention have also been carried out. Karabulut, (2016) ${ }^{[49]}$ conducted a study on the personality traits and its effect on entrepreneurial intention to the Turkey's students. His study identified several personality traits such as internal locus of control, need for achievement, risk-tolerance and entrepreneurial alertness and how they affect the entrepreneurial intention. His study led to a conclusion that all personality traits included in the study was correlated to the entrepreneurial intention. Similar study was conducted by Asmara, Djatmika and Indrawati (2016) ${ }^{[12]}$ on the Malang University students, Indonesia. Their study wanted to find out if needs for achievement and risk propensity have influenced over entrepreneurial intention. It was found that the two entrepreneurial attitudes are correlated to the entrepreneurial intention. The study also pointed out that the strongest positive effect was found in effect of need for achievement on entrepreneurial intention. The same study was also conducted by Phuong and Hieu (2015) ${ }^{[74]}$ on the predictors of entrepreneurial intentions of undergraduate students in Vietnam. His study found that individual difference variables such as risk-taking propensity and creativity and personality traits, such as locus of control and need for achievement had strong impacts on the intention to start a new venture. Jao, Scott and Lumpkin (2009) [44] confirmed that risk taking propensity and need for achievement are related to business intentions but not related to business performance. Yurtkoru, Acar and Teraman (2014) ${ }^{[102]}$ undertook similar study to measure the effect of personality trait along risk propensity and entrepreneurial intention of students. The study has the same finding as other researchers interested in the same topic that risk taking propensity is considered distinguishing factor for entrepreneurs and have an influence over the business intentions. Venesaar (2006) [100] pointed out that the personal characteristics and behavior typical of entrepreneur are correlated positively with the intention to start a new venture in the near future. Ozaralli and Rivenburgh (2016) ${ }^{[70]}$ presented similar finding that there is a statistically significant relationship among personality attributes of optimism, innovativeness, risktaking propensity and entrepreneurial intention.

Personality traits may not be enough to predict entrepreneurial intention because family background can also have an effect on the entrepreneurial intention of students. Busige (2015) ${ }^{[17]}$ conducted a study on the effect of personality trait and socio demographic background of students of the University of Colombo on their entrepreneurial career in the future. The students were assessed on three personality traits such risk taking propensity, internal locus of control and need for achievement, and three socio-demographic factors which are related to their personal background such as parents' occupation, gender and previous self-employment experience. The results revealed that there is a significant relationship between personality traits and entrepreneurial intention. However, the effect of socio-demographic background such parents' occupations and self-employment experience for developing entrepreneurial intention among the business students is relatively low in the Srilankan context. Srilankan context is similar to the Philippines' context that entrepreneurial intention is not affected by socio-demographic profiles (Ramos, 2014) ${ }^{[75]}$. However their case may not be the same true in other context as pointed out by Venesaar (2006) ${ }^{[100]}$ that there is a connection between students' status and background to their entrepreneurial intentions. Yildirim, Cakir, and Askun (2016) ${ }^{[101]}$ also agreed with Venesaar that personal history, background, social context, attitudes toward entrepreneurship, planned behavior and personality traits are pointed out as factors that have impact on the propensity to engage in entrepreneurship. This was also confirmed by the study of Dogan (2015) ${ }^{[26]}$ that social background such as self-employed parents has influenced entrepreneurial intention of the students.

\section{Conceptual Framework}

Independent Variables

Entrepreneurial Attitude:

Need for Achievement

Need for

Autonomy/Independence

Creative Tendency

Calculated Risk Takin

Drive and Determination
Dependent Variables

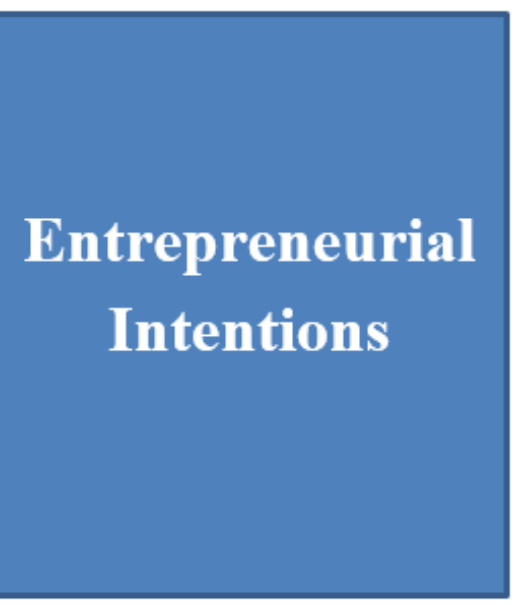

Fig 1: conceptual framework reflects the correlation between entrepreneurial attitude and entrepreneurial intentions 


\section{Statement of the Problems}

The study would like to measure the entrepreneurial attitude and entrepreneurial intention of the ABM Senior High School students of Divine Word Colleges in Region I, specifically it seeks to answer the following questions:

1. What is the entrepreneurial attitude of ABM Senior High School of Divine Word Colleges in terms of:

a. Need for achievement

b. Need for autonomy/independence

c. Creative tendency/innovation

d. Calculated risk taking

e. Drive and determination

2. What is the level of entrepreneurial intention of $A B M$ students of Divine Word Colleges in Region I?

3. Is there a relationship between entrepreneurial attitude and entrepreneurial intention?

\section{Assumption}

The study assumes that the questionnaires are valid and entrepreneurial attitude and entrepreneurial intentions can be measured.

\section{Hypothesis}

Karabulut (2016) ${ }^{[49]}$ and Asmara, Djatmika and Indrawati (2016) ${ }^{[12]}$ in their studies on the entrepreneurial attitude and entrepreneurial intentions found a correlation between entrepreneurial attitudes and intentions and therefore this study hypothesizes that there is a relationship between entrepreneurial attitude and entrepreneurial intention.

\section{Scope and Delimitation of the Study}

The study is only to measure the relationship between entrepreneurial attitude and entrepreneurial intention of the ABM grade XII Senior High School students of Divine Word Colleges in Region I which covers the three colleges such as Divine Word College of Vigan, Divine Word College of Bangued and Divine Word College of Laoag.

\section{Research Methodology}

In order to carry out the study, an appropriate research methodology is utilized. Therefore, this part will discuss research design, data gathering instruments, population, locale of the study, data gathering procedures and statistical treatment of data.

\section{Research Design}

Since the study is a quantitative research, thus, the study used quantitative descriptive research design and explanation research to determine the level of entrepreneurial attitude and entrepreneurial intentions of students. It describes what is found in the data. It involves the description, recording, analysis and interpretation based on the data gathered through questionnaires which are statistically computed. It is a fact finding with adequate interpretation. It assesses, determines and reports the way things are. In other words, it describes the data that have been collected on research sample, describes "what is" about the data gathered.

In line with the current study, descriptive assessment and correlational method was deployed. The study assessed the entrepreneurial attitude and how it affects their entrepreneurial intentions. This was to identify what the dominant entrepreneurial attitudes among students were and what particular entrepreneurial attitude does affect the entrepreneurial intentions.

\section{Locale of the Study}

The locale of the study was Divine Word Colleges in Region I which is composed of Divine Word College of Vigan. Divine Word College of Vigan is belonged to the Province of Ilocos Sur and located within the heritage city of Vigan. Divine Word College of Laoag is located in Laoag City, Ilocos Norte and Divine Word College of Bangued located in Abra Province. Divine Word Colleges in region I are run by the Congregation of the Divine Word Missionaries or known as Society of the Divine Word or in Latin, Societas Verbi Divini (SVD).

Population

The population of the study was composed of all ABM grade XII Senior High School students of Divine Word Colleges in Region I. Since the total numbers of students are limited, and therefore total enumeration or 162 students is the sampling design of the study.

\section{Data Gathering instruments}

The study utilized questionnaires. The questionnaires were adapted from the study of Fitzsimmons, Douglas (2005) Ramos (2014) ${ }^{[75]}$ and Asmara, Djatmika an Indrawati $(2016)^{[12]}$.

\section{Data Gathering Procedures}

In the process of data gathering, the researcher sent letters to the President of the Colleges, requesting them to allow the researcher to flow his questionnaires in the college. The researcher personally met the Presidents and students and requested them to answer the questionnaires.

The retrieval of questionnaires was arranged between the President's representative and the researcher with the help of employees and faculty of the college.

\section{Statistical Treatment of Data}

In consistent with the study as descriptive research, therefore descriptive statistics is used. The weighted mean and the Pearson $r$ will be used to measure the level of entrepreneurial attitudes and intentions and their correlations.

The following ranges of values with their descriptive interpretation will be use

\begin{tabular}{|c|c|c|}
\hline Statistical Range & Descriptive interpretation & Overall Descriptive Rating \\
\hline $4.21-5.00$ & Very true & Very High \\
\hline $3.41-4.20$ & True & High \\
\hline $2.61-3.40$ & Somewhat true & Moderate \\
\hline $1.81-2.60$ & Not true & Low \\
\hline $1.00-1.80$ & Not at all true & Very Low \\
\hline
\end{tabular}




\section{Findings}

The presentation of the findings is structured according to the arrangement of the statement of the problems. The findings are presented on the table and explained based on the data presented on the table.
Problem 1a: What is the entrepreneurial attitude of Grade XII ABM students of Divine Word Colleges in Region I in terms of need for achievement?

Table 1a: Entrepreneurial attitude of students in terms of Need for achievement

\begin{tabular}{|c|c|c|c|}
\hline & & $\overline{\boldsymbol{X}}$ & DR \\
\hline 1. & When I have to set my own goals, I set difficult rather than easy ones & 3.38 & True/High \\
\hline 2. & I usually defend my point of view if someone disagrees with me & 3.67 & True/High \\
\hline 3. & I think more of the present and the future rather than the past & 3.92 & True/High \\
\hline 4. & It is more important to do a job well than to try to please people & 3.99 & True/High \\
\hline 5. & I would rather take the responsibility for myself rather than being dependent on a team & 3.76 & True/High \\
\hline 6. & I like challenges that really stretch my abilities rather than things that I can do easily. & 3.81 & True/High \\
\hline 7. & If I am having problems with a task, I will not leave it but I stick it out until I get the result. & 3.72 & True/High \\
\hline 8. & I get annoyed when people are not on time to work & 3.69 & True/High \\
\hline 9. & I get up early, stay late and skip meals in order to get special assignment done & 3.35 & Somewhat true/moderate \\
\hline 10. & I just need to focus on the task needed to achieve my dreams & 4.04 & True/High \\
\hline & & 3.73 & True/High \\
\hline
\end{tabular}

Legend

$\begin{array}{llll}4.21 & 5.00 & \text { Very true } & \text { Very High } \\ 3.41 & 4.20 & \text { True } & \text { High } \\ 2.61 & 3.40 & \text { Somewhat true } & \text { Moderate } \\ 1.81 & 2.60 & \text { Not true } & \text { Low } \\ 1.00 & 1.80 & \text { Not at all true } & \text { Very Low }\end{array}$

As gleaned from the data presented on the table, it shows that over all entrepreneurial attitudes of students in terms of need for achievement is high or 3.73. Taking them singly, most of the questions asked under this variable were all evaluated high. There is only one question is evaluated somewhat true or moderate which is question number 9 in which the students must "get up early, stay late and skip meals in order to get the special assignment done" (3.35). However, as a whole, the students have high need for achievement. Therefore overall, students like to set difficult task, defend their point of views, prioritize the future and not the present, focus more on the task and not pleasing people, not depending on others, challenge their abilities and discipline themselves to get the result, sacrifice their pleasure in order to get the job done to achieve their dreams. Problem 1b: What is the entrepreneurial attitude of Grade XII ABM students of Divine Word Colleges in Region I in terms of need for autonomy?

Table 1b: Need for Autonomy

\begin{tabular}{|c|c|c|c|}
\hline & ITEMS & $\overline{\bar{X}}$ & DR \\
\hline 1. & I like to do thing in an unconventional way & 3.33 & Somewhat true/Moderate \\
\hline 2. & When I am in group I am not happy to let someone else take the lead. & 2.70 & Somewhat true/moderate \\
\hline 3. & $\begin{array}{l}\text { When I am faced with a challenge, I think more about the results of } \\
\text { succeeding than the effects of failing }\end{array}$ & 3.77 & True/high \\
\hline 4. & I like to do things in my own way without worrying about what other people thinks & 3.56 & True/high \\
\hline 5. & When tackling a task I rarely need help & 3.31 & Somewhat true/high \\
\hline 6. & Most people think than I am stubborn & 3.27 & Somewhat true/high \\
\hline 7. & I prefer working alone than with other people & 3.45 & True/high \\
\hline 8 & I do not bow to group pressure & 3.20 & Somewhat true/moderate \\
\hline 9. & I dislike taking orders & 2.96 & Somewhat true/moderate \\
\hline 10. & I need to express what I think & 3.86 & True/high \\
\hline & Overall & 3.34 & Somewhat true/moderate \\
\hline
\end{tabular}

$\begin{array}{llll}4.21 & 5.00 & \text { Very true } & \text { Very High } \\ 3.41 & 4.20 & \text { True } & \text { High } \\ 2.61 & 3.40 & \text { Somewhat true } & \text { Moderate } \\ 1.81 & 2.60 & \text { Not true } & \text { Low } \\ 1.00 & 1.80 & \text { Not at all true } & \text { Very Low }\end{array}$

As reflected in the computation of data presented on the table, it reveals that overall the students have somewhat true or moderate (3.34) need for autonomy. Taking them singly, most of the questions asked under this variable were evaluated moderate particularly questions number 1 , "doing task in unconventional way" (3.33), 2, "not happy to let someone else to take the lead" (2.70), 5, "when talking a job, I rarely need help" (3.31), 6, " most people think I am stubborn" (3.27), 8, "I do not bow to group pressure" (3.20), 9, "I dislike taking orders" (2.96). There were four questions evaluated high under this variable particularly questions number 3, "When I am faced with a challenge, I think more about the results of succeeding than the effects of failing" (3.77), 4, "I like to do things in my own way without worrying about what other" (3.56), 7, "I prefer working 
alone than with other people" (3.34), and 10, "I need to express what I think" (3.86).
Problem 1c: What is the entrepreneurial attitude of Grade XII ABM students of Divine Word Colleges in Region I in terms of creative tendency?

Table 1c: Creative Tendency

\begin{tabular}{|c|c|c|c|}
\hline & Items & $\bar{X}$ & DR \\
\hline 1. & I always have day dream & 3.70 & True/High \\
\hline 2. & Sometimes people find my ideas unusual & 3.31 & Somewhat true/moderate \\
\hline 3. & I do not like guessing & 3.15 & Somewhat true/Moderate \\
\hline 4. & Other people think that I ask a lot of questions & 3.25 & Somewhat true/moderate \\
\hline 5. & I do not like to have my life organized & 2.51 & Somewhat true/moderate \\
\hline 6. & I can handle a lot of things at the same time & 3.30 & Somewhat true/moderate \\
\hline 7. & I like to find out about things even if it means handling some problems while doing so. & 3.39 & Somewhat true/moderate \\
\hline 8. & I like sudden changes in my life & 3.43 & True/high \\
\hline 9. & I do not want to do things in the usual ways & 3.12 & Somewhat true/moderate \\
\hline 10. & It is not hard for me to adapt to change & 3.40 & Somewhat true/moderate \\
\hline & Overall & 3.26 & Somewhat true/moderate \\
\hline
\end{tabular}

Legend

$\begin{array}{llll}4.21 & 5.00 & \text { Very true } & \text { Very High } \\ 3.41 & 4.20 & \text { True } & \text { High } \\ 2.61 & 3.40 & \text { Somewhat true } & \text { Moderate } \\ 1.81 & 2.60 & \text { Not true } & \text { Low } \\ 1.00 & 1.80 & \text { Not at all true } & \text { Very Low }\end{array}$

Based on the computed mean as shown on the table, it reveals that overall the creative tendency of the students are considered somewhat true or moderate (3.26). Taking them singly, it appears that majority of the questions were evaluated within the moderate range particularly questions number 2, "Sometimes people find my ideas unusual" (3.31), 3, "I do not like guessing" (3.15), 4, "Other people think that I ask a lot of questions" (3.25), 5, "I do not like to have my life organized" (2.51), 6, "I can handle a lot of things at the same time" (3.30), 7, "I like to find out about things even if it means handling some" (3.39), and 9, "I do not want to do things in the usual ways" (3.12). There are only three questions are evaluated true or high particularly questions number 1, "I always have day dream" (3.70), 8, "I like sudden changes in my life" (3.43), and 10, "It is not hard for me to adapt to change" (3.40).

Problem 1d: What is the entrepreneurial attitude of Grade XII ABM students of Divine Word Colleges in Region I in terms of calculated risk taking?

Table 1d: Calculated Risk Taking

\begin{tabular}{|c|c|c|c|}
\hline \multicolumn{2}{|r|}{ ITEMS } & \multirow{2}{*}{$\begin{array}{c}\overline{\boldsymbol{X}} \\
3.43\end{array}$} & \multirow{2}{*}{$\begin{array}{c}\text { DR } \\
\text { True/High }\end{array}$} \\
\hline 1. & $\begin{array}{c}\text { When I have to set my own targets, I will proceed even if it is not certain that I will get } \\
\text { it }\end{array}$ & & \\
\hline 2. & $\begin{array}{l}\text { If I had a good idea for making some money, I would be willing to borrow some money } \\
\text { to enable me to }\end{array}$ & 3.37 & Somewhat true/moderate \\
\hline 3. & If there is a chance of failure, will still try to do it & 3.81 & True/High \\
\hline 4. & $\begin{array}{c}\text { I would rather take an opportunity that might lead to even better things than have an } \\
\text { experience I am sure to enjoy }\end{array}$ & 3.68 & True/High \\
\hline 5. & I do not find it difficult to ask favors from other people & 3.38 & Somewhat true/moderate \\
\hline 6. & I will take risk if the chances of success are & 3.68 & True/high \\
\hline 7. & $\begin{array}{c}\text { Before making important decisions, I prefer to weigh up the pros and cons quickly rather } \\
\text { than spending a lot of time thinking about it }\end{array}$ & 3.34 & Somewhat true/moderate \\
\hline 8. & $\begin{array}{c}\text { Before making important decisions, I prefer to weigh up the pros and cons quickly rather } \\
\text { than spending a lot of time thinking about it. }\end{array}$ & 3.52 & True/High \\
\hline 9. & I prefer the unfamiliar rather than what we are used to. & 3.33 & Somewhat true/Moderate \\
\hline 10. & I like to start new projects that may be risky & 3.22 & Somewhat true/moderate \\
\hline & Overall & 3.48 & True/High \\
\hline
\end{tabular}

Legend

$\begin{array}{llll}4.21 & 5.00 & \text { Very true } & \text { Very High } \\ 3.41 & 4.20 & \text { True } & \text { High } \\ 2.61 & 3.40 & \text { Somewhat true } & \text { Moderate } \\ 1.81 & 2.60 & \text { Not true } & \text { Low } \\ 1.00 & 1.80 & \text { Not at all true } & \text { Very Low }\end{array}$

As reflected on the computed mean, it shows that overall the students have a high calculated risk taking attitude as shown in its computed mean of 3.48. However, taking them singly, not all questions were rated high but moderate particularly questions number 2, " If I had a good idea for making some money, I would be willing to borrow some money to enable me to do it" (3.37), 5, "I do not find it difficult to ask favors from other people"(3.38), 7, "Before making important decisions, I prefer to weigh up the pros and cons quickly rather than spending a lot of time thinking about it"(3.34), 9, "I prefer the unfamiliar rather than what we are used to" (3.33), and 10, ".I like to start new projects that may be 
risky" (3.22). There are five questions are rated high under this variable particularly questions number 1 , "When I have to set my own targets, I will proceed even if it is not certain that I will get it" (3.43), 3, ". If there is a chance of failure, will still try to do it" (3.81), 4," I would rather take an opportunity that might lead to even better things than have an experience I am sure to enjoy" (3.68), 6, "I will take risk if the chances of success are" (3.68), and 8, "Before making important decisions, I prefer to weigh up the pros and cons quickly rather than spending a lot of time thinking about it" (3.52).

Problem 1e: What is the entrepreneurial attitude of Grade XII ABM students of Divine Word Colleges in Region I in terms of drive and determination?

Table 1e: Drive and Determination

\begin{tabular}{|c|c|c|c|}
\hline \multicolumn{2}{|c|}{ ITEMS } & $\overline{\boldsymbol{X}}$ & DR \\
\hline 1. & If I want to be successful I have to take chances when they occur & 4.02 & True/ High \\
\hline 2. & If I want to be good at one thing, I have to work hard & 4.26 & True/High \\
\hline 3. & People generally get what they deserve & 3.94 & True/high \\
\hline 4. & I do not need to please people with control over me to get what I want. & 3.61 & True/high \\
\hline 5. & For me, getting what I want has little to do with luck & 3.40 & Somewhat true/moderate \\
\hline 6. & What happen to me in life is not determined by other people & 3.70 & True/high \\
\hline 7. & Many of the bad times that people experience are not due to bad luck & 3.55 & True/high \\
\hline 8. & When I make plans to do something, I always do what I plan & 3.57 & True/high \\
\hline 9. & uccess is not determined by the place and time & 3.70 & True/high \\
\hline 10. & Being successful is the result of working hard, luck has nothing to do with & 3.93 & True/high \\
\hline & Overall & 3.77 & True/high \\
\hline
\end{tabular}

Legend

4.21 5.00 Very true Very High

3.41 4.20 True High

$2.61 \quad 3.40$ Somewhat true Moderate

$1.81 \quad 2.60$ Not true Low

$1.00 \quad 1.80$ Not at all true Very Low

As presented on the table, it reflects that as an overall the entrepreneurial attitude of students in terms of drive and determination is considered high as indicated by its computed value of 3.77 which means true or high. Taking them singly, it also shows that most of the questions were rated high particularly questions number 1, "If I want to be successful I have to take chances when they occur" (4.02), 2," If I want to be good at one thing, I have to work hard" (4.26), 3, " People generally get what they deserve"(3.94), 4 , "I do not need to please people with control over me to get what I want" (3.61), 6, "What happen to me in life is not determined by other people"(3.70), 7, "Many of the bad times that people experience are not due to bad luck" (3.55), 8 , "When I make plans to do something, I always do what I plan" (3.57), 9, "Success is not determined by the place and time" (3.70, and 10, "Being successful is the result of working hard, luck has nothing to do with" (3.93). There is only one question particularly question number 5 , "For me, getting what I want has little to do with luck" (3.40).

Table 2: Summary Level of Entrepreneurial Attitude

\begin{tabular}{|c|c|c|}
\hline & $\overline{\boldsymbol{X}}$ & DR \\
\hline Need for Achievement & 3.73 & True/high \\
\hline Need for Autonomy & 3.34 & Somewhat true/moderate \\
\hline Creative Tendency & 3.26 & Somewhat true/moderate \\
\hline Calculated Risk Taking & 3.48 & True/high \\
\hline Drive and Determination & 3.77 & True/high \\
\hline Overall & 3.52 & True/high \\
\hline
\end{tabular}

4.21 5.00 Very true Very High

3.41 4.20 True High

2.613 .40 Somewhat true Moderate

1.812 .60 Not true Low

1.001 .80 Not at all true Very Low

In summary, as shown on the table, the overall entrepreneurial attitude of the students are considered high with the mean of 3.52. However taking them singly, not all were rated high but moderate particularly need for autonomy (3.34) and creative tendency 9326). There are three entrepreneurial attitudes that are rated high particularly need for achievement (3.73), calculated risk taking (3.48), and drive and determination (3.77).

Problem 2. What is the entrepreneurial intention of grade XII ABM students of Divine Word Colleges in Region 1? 
Table 4: Entrepreneurial Intentions

\begin{tabular}{|c|c|c|c|}
\hline \multicolumn{2}{|c|}{ ITEMS } & $\overline{\boldsymbol{X}}$ & DR \\
\hline 1 & My professional goal is to become an entrepreneur & 3.53 & True/high \\
\hline 2. & I will make every effort to start and run my own business & 3.81 & True/high \\
\hline 3. & I am determined to establish a business in the future & 3.86 & True/high \\
\hline 4. & I am seriously considering of putting up a business in the future & 3.81 & True/high \\
\hline 5. & I have the firm intention to start a firm someday & 3.75 & True/high \\
\hline 6. & I am ready to do anything to be an entrepreneur & 3.63 & True/high \\
\hline 7. & If I will open a business, I have a chance to become successful & 3.71 & True/high \\
\hline 8. & Being an entrepreneur would make me great & 3.65 & True/high \\
\hline 9. & I have ideas about how to start a business in the future & 3.77 & True/high \\
\hline 10. & It would be difficult for me to develop business ideas & 3.21 & Somewhat true/moderate \\
\hline & Overall & 3.67 & True/high \\
\hline
\end{tabular}

Legend

$\begin{array}{llll}4.21 & 5.00 & \text { Very true } & \text { Very High } \\ 3.41 & 4.20 & \text { True } & \text { High } \\ 2.61 & 3.40 & \text { Somewhat true } & \text { Moderate } \\ 1.81 & 2.60 & \text { Not true } & \text { Low } \\ 1.00 & 1.80 & \text { Not at all true } & \text { Very Low }\end{array}$

As indicated on the table, it reveals that overall the Grade XII ABM Senior High School of Divine Word Colleges in Region 1 have a high entrepreneurial intentions as shown in its average mean of 3.67 which is true or high. Taking them singly, most of the questions under this variable are rated high, except question number 10, "It would be difficult for me to develop business ideas" (3.21).

Problem 3: is there a relationship between entrepreneurial attitude and entrepreneurial intention?

Table 3: Relationship between entrepreneurial attitude and entrepreneurial intentions

\begin{tabular}{|c|c|}
\hline Need for achievement & $0.4062^{*}$ \\
\hline Need for autonomy & $0.2501 *$ \\
\hline creative tendency & $0.2310^{*}$ \\
\hline calculated risk taking & $0.3948^{*}$ \\
\hline Drive and determination & $0.4880^{*}$ \\
\hline As a whole & $0.3540 *$ \\
\hline *Significant at 0.05 level
\end{tabular}

As revealed on the table, it shows that as a whole, there is significant a correlation between entrepreneurial attitude and entrepreneurial intentions at 0.05 level. Taking them singly, it also shows that all entrepreneurial attitude variables are correlated to entrepreneurial intentions. It just means that need for achievement, need for autonomy, creative tendency, calculated risk taking and drive and determination influence entrepreneurial intentions of the students in the future.

\section{Conclusion}

The study concludes that as a whole the entrepreneurial attitude of students are considered high or 3.52. There are three variables are rated high such as need for achievement (3.73), calculated risk taking (3.48) and drive and determination (3.77). There were two entrepreneurial attitudes that are rated moderate such as need for autonomy (3.34) and creative tendency (3.26). In terms of its correlation with entrepreneurial intentions, the computed value reveals that there is a correlation. Therefore, the hypothesis is accepted.

\section{Recommendation}

Karabulut (2016) ${ }^{[49]}$ and Asmara, Djatmika and Indrawati (2016) ${ }^{[12]}$ in their studies on the entrepreneurial attitude and entrepreneurial intentions found a correlation between entrepreneurial attitudes and intentions, therefore this study recommends that the administrator or curriculum developer should design programs and activities that boost the entrepreneurial attitude of students to motivate them into business in the future. This is in line with what Monitor (GEM) has been saying that proactive approach in the developing of EB (entrepreneurial behavior) and enhancing entrepreneurial intentions requires consistent improving of entrepreneurship education (Singer, Amoros, Arreola, 2015) [91]. Kritskaya, (2015) [51] argued that entrepreneurship education programs are the right and effective tool to enhance entrepreneurial intentions.

\section{References}

1. Abbas LN. Engineering Students: What factors effects their entrepreneurial intention? 2013.

2. IOSR Journal Of Humanities And Social Science (IOSR-JHSS). 2013; 15(2):35-40.

3. Abdul Raham A. Perkerjaan dalam kehindupan. Malaysia, Petaling Jaya: Prentice Hall, 2000.

4. Adams J (nd). 10 Qualities of a Successful Entrepreneur. Retrieved from http://under30ceo.com/10-qualities-of-a-successfulentrepreneur/

5. Ajzen I, Fishbein M. Attitude-behavior Relations: A Theoretical Analysis and Review of Empirical Research. Psychological Bulletin. 1977; 84(5):888-918.

6. Ajzen I. Theory of Planned Behaviour. Organizational Behaviour and Human Decisions

7. Processes. 1991; 50:2, 179-211.

8. Ajzen I. Perceived behavioural control, self-efficacy, locus of control and the theory planned behaviour. Applied Social Psychology. 2002; 32:1-20.

9. Allah MA, Nakhaie H. Entrepreneurship and risk taking. International Conference on E-business, Management and Economics. IPEDR. 2011; Vol.25 IACSIT Press, Singapore.

10. Angyal A. Disgust and related aversions. Journal of Abnormal and Social Psychology. 1941; 36: 393-412. doi: $10.1037 / \mathrm{h} 0058254$

11. Anastasia. Why Creativity is so Crucial for Entrepreneurs? In Cleverism. Retrieved from, 2015. https://www.cleverism.com/why-creativity-is-socrucial-for-entrepreneurs/ 
12. Asmara HW, Djatmika ET, Indrawati A. The Effect of Need for Achievement and Risk Taking Propensity on Entrepreneurial Intention through Entrepreneurial Attitude. IOSR Journal of Business and Management (IOSR-JBM). 2016; Volume 18, Issue 6, Ver. I, Jun, PP 117-126

13. Assor A, Kaplan H, Roth G. Choice is good, but relevance is excellent: Autonomy-enhancing and suppressing teacher behaviours predicting students'engagement in schoolwork. British Journal of Educational Psychology. 2002; 72, 261-278.

14. Badal SB (nd). Great Entrepreneurs are Creative Thinkers. Retrieved from https://www.creativityatwork.com/2014/08/22/greatentrepreneurs-creative-thinkers/

15. Bradley RJ. "Toward a Multidimensional Model of Entrepreneurship: The Case of Achievement Motivation and the Entrepreneur. Entrepreneurship: Theory and Practice. 1990; 14(3), 39135-147

16. Brown S, Warner J. Using daily stock returns: The case of event studies, Journal of Financial Economics. 1985; 14:3-31.

17. Busige N. Influence of Personality Traits and Sociodemographic Background of Undergraduate Students on Motivation for Entrepreneurial Career: The Case of Sri Lanka, 2015.

18. BusinessDictionary (nd). Psychological Drives. Retrieved from http://www.businessdictionary.com/definition/psycholo gical-drives.html

19. Caird S. General Measure of Enterprising Tendency Test. Open Research Online. Retrieved from, 2013. www.get2test.net.

20. Carney K. "Who's Who in Small-Business Research." Inc. 1995; 17(7):56-63.

21. Catalano RF, Berglund ML, M Ryan JM, Lonczak HS, Hawkins JD. "Positive youth development in the United States: research findings on evaluations of positive youth development programs," Annals of the American Academy of Political and Social Science. 2004; vol.591, pp.98-124.

22. Cox JL. Understanding Entrepreneurship. Retrieved from 2011. https://www.ctahr.hawaii.edu/sustainag/news/articles/V 7-Cox-entrepreneurship.pdf

23. Deci EL, Ryan RM. Intrinsic Motivation and Selfdetermination in Human Behavior. New York: Plenum, 1985.

24. Deci EL, Ryan RM. The "what" and "why" of goal pursuits, 2000.

25. Desai V. Dynamics of Entrepreneurial Development and Management. Himalaya Publishing House, Mumbai, 2001.

26. Dogan E. The Effect of Entrepreneurship Education on Entrepreneurial Education on the Entrepreneurial Intention of University Students in Turkey. Ekonometri ve İstatistik Sayı. 2015; Vol.23, 79-93

27. Duxbury D, Summers B. Financial risk perception: Are individuals variance averse or loss averse? Economic Letters. 2004; volume 84, no.1, 21-28

28. Encyclopedia Britanica (nd). Drive Behavior. Retrieved from https://www.britannica.com/topic/drive

29. Fadel H. Education Reform to Create Entrepreneurs. Published in World Bank Publication. Retreived from.
2016. http://blogs.worldbank.org/arabvoices/educationreform-create-entrepreneurs

30. Fayolle A, Gailly B, Lassas-Clerk N. Capturing Variations in Attitude and Intentions: A, 2005.

31. Longitudinal Study to Assess the Pedagogical Effectiveness of Entrepreneurship

32. Teaching Programmes, Working Paper of EMLYON of the European Institution for

33. Life Long Learning.

34. Francis DH, Banning $\mathrm{K}$. Who wants to be an entrepreneur? Journal of Academy of Business Education. 2001; 1(2), 5-11.

35. FULL FABRIC. The Role of Higher Education in Nurturing Entrepreurship. Retrieved from, 2017. http://blog.fullfabric.com/role-higher-educationnurturing-entrepreneurship-entrepreneurialismuniversity-students

36. Gartner WB.A Conceptual Framework for Describing the Phenomenon of New Venture Creation. The Academy of Management Review. 1985; 10(4), 696706.

37. Gimeno J, Folta TB, Cooper AC, Woo C Y. Survival of the fittest? Entrepreneurial human capital and the persistence of underperforming firms. Administrative Science Quarterly. 1997; volume 42, 750-783.

38. Gould S. Drive, Determination and Passion: Three Keys to Success in Life and in Business. Retrieved from, 2014. https://www.linkedin.com/pulse/20140620185038334219545-drive-determination-and-passion-threekeys-to-success-in-business-and-in-life/

39. Graham Sandra. "Motivation in African Americans." Review of Educational Research. 1994; 64(1): 55-117.

40. Hannan M, Hazlett SA, Leitch C. Entrepreneurship Education: How Do We Measure, 2004.

41. Success? Working paper, Queen's University Belfast.

42. Hannon PD. The Journey from Student to Entrepreneur. A Review of the Existing, 2005.

43. Research into Graduate Entrepreneurship. Paper presented at the IntEnt, 2005.

44. Hao Jao H, Scott E, Seibert GTL. The Relationship of Personality to Entrepreneurial Intentions and Performance: A Meta-Analytic Review. SAGE Journal of Management, 2009.

45. Hull CL. Principles of behavior. New York: AppletonCentury-Crofts, 1943.

46. Human needs and the Self-determination of Behaviour. (n.d) Psychological Inquiry. 11(4), 227-268.

47. Investopedia (nd) Entrepreneur. Retrieved from https://www.investopedia.com/terms/e/entrepreneur.asp

48. Kao RWY, Kao KR, Kao RR. Entrepreneurism. London: Imperial College Press, 2002.

49. Karabulut AT. Personality Traits on Entrepreneurial Intention. Procedia - Social and Behavioral Sciences. 2016; 229:12-21.

50. Kirby LD, Morrow J, Yih J. The challenge of challenge: Pursuing determination as an emotion. In MM Tugade MN, Shiota, LD. Kirby (Eds.), Handbook of Positive Emotions. New York: Guilford Publications, Inc, 2014.

51. Kritskaya L. Effect of Entrepreneurship Education on Students' Entrepreneurial Intentions. Master Thesis, University of Agder, Russia, 2015. 
52. Korunka C, Frank H, Lueger M, Mugler J. The Entrepreneurial Personality in the Context of Resources, Environment, and the Start- up Process -A Configurational Approach. Entrepreneurship Theory and Practice. 2003; 28(1):23-42.

53. Landrine H. "Clinical Implications of Cultural Differences: The Referential Versus the Indexical Self. Clinical Psychology Review. 1992; 12: 401-415.

54. Lee L, Wong PK, Foo MD. Entrepreneurial intentions: The influence of organizational and individual factors. ELSEVIER. 2009.Doi.org/10.1016/j.jbusvent.2009.003.

55. Lumpkin GT, Dess GG. Enriching the entrepreneurial orientation construct: A reply to "Entrepreneurial orientation or pioneer advantage." Academy of Management Review. 1996; volume 21, no.3, 605-607.

56. Lüthje C, Franke N. The Making of an entrepreneur: Testing a Model of, 2003.

57. Entrepreneurial intent among Engineering Students at MIT, R\&D Management, 33.

58. MacCrimmon KR, Wehrung DA. Taking risks: The management of uncertainty. Auburn: Free Press, 1986.

59. Maehr ML, Nicholls JG. "Culture and Achievement Motivation: A Second Look." In N. Warren (Ed.), Studies in Cross-Cultural Psychology. 1980; 2:221-267.

60. Manisha, Singh RK. Students Attitude toward Entrepreneurship. Delivered at Fourth International Conference On Recent Innovations in Science Engineering and Management. Retrieved from, 2016. www.conferenceworld.in

61. March JG, Shapira Z. Managerial Perspectives on Risk and risk Taking. Management Science. 1987; 33(11):1404-1418.

62. Marescha D, Kailerc N, Wimmer-Wurmc B. The impact of entrepreneurship education on the entrepreneurial intention of students in science and engineering versus business studies university programs. International Journal of Technological Forecasting and Social Change. 2015; 104:172-179

63. McClelland DC. The Achieving Society. New York: Irvington, 1961.

64. Mohd Salleh Hj Din. Pembangunam Keusahawanan: Cabaran kepada pendidikan tinggi. Professor enhancement lecture series Sintok: Universiti Utara Malasia Publishing, 2002.

65. Murray H. Explorations in Personality. New York: Oxford University Press, 1938.

66. Niham Yildirim, Ozgur Cakir, Olcay Bige Askun. Ready to Dare? A Case Study on Entrepreneurial Intentions of Business and Engineering Students in Turkey, 2016.

67. Nishantha B. Influence of Personality Traits and Sociodemographic Background of Undergraduate Students on Motivation for Entrepreneurial Career:The Case of Sri Lanka. Retrieved from, 2015. https://www.scribd.com/doc/12913556/entrepreneurialIntention.

68. Nota L, Soresi S, Ferrari L, Wehmeyer ML. A multivariate analysis of the self-determination of adolescents, Journal of Happiness Studies. 2011; 12:245-266.

69. OECD. Understanding Entrepreneurship: Developing Indicators for International Comparisons and Assessments. Retrieved from, 2006. http://www.oecd.org/officialdocuments/publicdisplaydo cumentpdf $/$ doclanguage $=$ en $\&$ cote $=$ STD $/$ CSTAT $(2006$ ) 9 .

70. Ozaralli N, Rivenburgh NK. Entrepreneurial intention: antecedents to entrepreneurial behavior in the USA and Turkey. Journal of Global Entrepreneurship Research, 2016. doi.org/10.1186/s40497-016-0047-X_

71. Paderanga CW. Private Sector Assessment, Philippines. Retrieved from 2011. https://www.adb.org/sites/default/files/institutionaldocument/32479/files/psa-philippines-2011.pdf.

72. Patel S. What Drives An Entrepreneur? Retrieved from, 2012. www.sujanpatel.com/business/what-drives-anentrepreneur

73. Peng Z, Lu G, Kang H. Entrepreneurial Intentions and Its Influencing Factors: A Survey of the University Students in Xi'an China. Creative Education. 2012; Vol.3, Supplement, 95-100.

74. Phuong TH, Thanh Trung Hieu TT. Predictors of Entrepreneurial Intentions of Undergraduate Students in Vietnam: An Empirical Study. International Journal of Academic Research in Business and Social Sciences. August 2015; Vol.5, No.8.

75. Ramos AM. Entrepreneurial intention among Business Students in Batangas State University. Asia Pacific Journal of Management Research. 2014; Vol.2, No.4.

76. Rentschler R. The Role of Cretaivity in Entrepreneurship. Journal of Enterprising Culture. 2010; Volume 18, Issue 01, March.

77. Resurrection PF. Determinants of Entrepreneurial Attitudes and Intentions among High School Students in Iligan City, 2011.

78. Richards RW. Of Entrepreneurship, its Nature and Nurturing. A presentation to the Search Committee for the chair in Youth-Focused Technological Entrepreneurship at Memorial University of Newfoundland, 1999.

79. Robinson PB, Stimpson DV, Huefner JC, Slater J. An attitude approach to prediction of entrepreneurship. Entrepreneurship Theory and Practice. 1991; 15(1): 13-31.

80. Robinson K (nd). Changing Education Paradigms. Retrieved from, 1991. https://www.ted.com/talks/ken_robinson_changing_edu cation_paradigms

81. Rogan M. How important is Education to Entrepreneurial Development. Published in INSEAD: Knowledge is Power. Retrieved from, 2015. https://knowledge.insead.edu/blog/insead-blog/howimportant-is-education-to-entrepreneurial-development4164

82. Rudhumbu N. Attitudes of Students towards Entrepreneurship Education at Two Selected Higher Education Institutions in Botswana: A Critical Analysis and Reflection. ResearchGate, 2016.

83. Salleh M. Pembangunam Keusahawanan: Cabaran kepada pendidikan tinggai. Professor enhancement lecture series Sintok: Universiti Utara Malasia Publishing, 2002.

84. Sarasvathy SD. What Makes Entrepreneur Entrepreneurial? Retrieved from, 2015. http://www.effectuation.org/sites/default/files/document s/what-makes-entrepreneurs-entrepreneurialsarasvathy.pdf 
85. Sataniewski MW. Student readiness to start their own business. Economic Research - Ekonomoska Istrazivanja, an open access journal. 2015; Vol.31.

86. Schultz PW, Oskamp. Effort as a moderator of the attitude behaviour relationship: general environmental concern and recycling. Social Psychology Q. 1996; 59:375-383.

87. Schumpeter JA. The Theory of Economic Development. Harvard University Press, Harvard, 1934.

88. Shapira Z. Externalities, selection processes and managerial risk taking, Evolutionary Dynamics of Organizations. New York: Oxford University Press, 1994.

89. Shaver KG. The Entrepreneurial Personality Myth. Business and Economic Review. 1995; 41(3):20-23.

90. Sidek NN. Perkenbangan Kerijaya: Teori dan Praktis. Serdang: Penenbit University Putra Malaysia, 2008.

91. Singer S, Amoros GE, Arreola DM. Global Entrepreneurship Monitor 2014 Global Report. Babson College, Babson Park, MA, United States, Universidad del Desarrollo, Santiago, Chile, Universiti Tun Abdul Razak, Kuala Lumpur, Malaysia, 2015.

92. Sondari CM. Is Entrepreneurship Education Really Needed? Examining the Antecedence of Entrepreneurial career Intentions. Procedia-Social and behavioral Sciences. 2014; 115:44-53.

93. Stimpson-David-V, Narayanan-Srinivasa, Shanthakumar-Daniel-K. Attitudinal Characteristics of Male and Female Entrepreneurs in the United States and India. Psychological Studies. 1993; 38(2):64-68.

94. The World Bank. Global Economic Prospects: BroadBased Upturn, but For How Long? Retrieved from, 2018. http://www.worldbank.org/en/publication/globaleconomic-prospects.

95. Timmons JA. New Venture Creation, Entrepreneurship for the 21st Century. Irwin, Burr Ridge, Illinois, Part IV Financing Entrepreneurial Ventures, 1994.

96. Toone EJ. The Role of Higher Education in Entrepreneurship. Retrieved from, 2016. https://techcrunch.com/2016/07/21/the-role-of-highereducation-in-entrepreneurship/

97. Tshikovhi N, Shambare R. Entrepreneurial knowledge, entrepreneurial attitudes, and entrepreneurship intentions among South African Enactus students, 2015.

98. Problems and Perspective in Management (OpenAccess), 13 (1-1)

99. Tung LC. The Impact of Entrepreneurship Education on the Entrepreneurial Intention of Engineering Students. Dissertation, University of Hong Kong, 2011.

100. Venesaar U. Students' Attitude and Intentions toward Entrepreneurship at Tallinn University of Technology. Research Gate, 2006.

101. Yildirim N, Cakir O, Askun OB. Ready to Dare? A Case Study on Entrepreneurial Intentions of Business and Engineering Students in Turkey. Procedia-Social and Behavioral Sciences. 2016; 229:277-288.

102. Yurtkoru ES, Acar P, Teraman BS. Willingness to take risk and entrepreneurial intention of university students: An empirical study comparing private and state universities. Procedia - Social and Behavioral Sciences. 2014; 150:834-840. 